\title{
Aspirations, Constraints, and Outcomes
}

\author{
ANDREW GLYN*
}

At the turn of the century more parties of the Left were in government in advanced capitalist countries than ever before, including, for the first time ever, those of the four largest West European countries. Does this make a substantial difference to the conduct of economic policy? Even 20 years ago the answer would have been clear. Mitterrand had just been elected to the presidency of France on a radical programme including extensive nationalization and he then proceeded with 'a barrage of reforms without precedent in post-reconstruction Europe' (Jensen and Ross, 1994, p. 172). By contrast, the Left's spectacular election victories in the UK and France in 1997 and then in Germany in 1998 brought far more modest shifts in economic policy. Labour promised a tougher attitude to inflation, ruled out the restoration of state benefits and abandoned its interventionist approach to industry. The French socialists have privatized at a faster rate than the right-wing governments they replaced. Oscar Lafontaine's attempt to push the Bundesbank into a more expansionary stance collapsed within 6 months. Within left parties generally there have been policy shifts in the same direction. How has this come about?

The majority of the chapters which follow approach this question by examining the experience of individual countries in the 1980s and 1990s. While not every country which had a left government is surveyed, a broad range of experience is covered. In Sweden and Austria the Left had long been dominant and had produced quite distinct social democratic 'models' of economic policy; in France, Greece, and Spain government by the Left was historically rather exceptional; Australia and New Zealand were in an intermediate position. In the UK the Left did not

* Corpus Christi College, Oxford.

I would like to thank the following for very helpful comments and suggestions: Chris Allsopp, Andrea Boltho, Wendy Carlin, David Soskice, Bob Sutcliffe, Frank Vandenbroucke, and the contributors to this volume. 
regain power until 1997, much later than the other countries considered here, and after 18 years of hard-core conservative rule. The role played by Solidarity in the overthrow of communism seemed to mark Poland out as the 'transition economy' where social democratic forces would be strongest, and Tadeusz Kowalik's chapter examines why a strong alternative social democratic economic policy did not develop there. Analysing these experiences brings out common factors behind the trend towards conservative orthodoxy. While economic constraints play a prominent role in the stories recounted in the papers, it is important to remember that these governments had many priorities other than narrowly economic ones. For example, consolidation of democratic rule or desire to join the EU helped shape economic policy in Southern Europe and Poland especially.

The three final chapters take a broader comparative view. Evelyne Huber and John Stephens analyse the evolution of the social democratic welfare states, arguably the one sphere in which social democratic parties can still claim a distinctive approach. Torben Iversen discusses the policy dilemmas in terms of employment, taxation, and inequality which Northern European social democracy faces. Finally, Adam Przeworski sets the current evolution of social democratic policy in an historical and ideological perspective.

Particular national histories and institutions, and their influence on options and outcomes, are a recurrent theme in the country studies. In this introduction, however, these national specificities are submerged in order to outline, first, the common aspirations of 'social democracy' or the parties of the Left (terms that will be used interchangeably), and then the economic trends which provided the context for social democratic rule in the 1980s and 1990s. Finally, a brief assessment is given of what was achieved.

\section{Aspirations}

The reference to 'social democracy' in the title of this volume indicates that the focus is on governments in the broad 'reformist socialist' tradition. Historically, this has encompassed parties envisaging a long process of transformation of capitalism into a socialist system, based on common ownership of the means of production, as well as parties accepting the authority and ownership structures of capitalism but pressing for reforms to increase economic efficiency and to reduce inequality (see Przeworski's chapter). The latter, revisionist, position has been associated with the 'social democracies' of Northern Europe (and the labour parties of Australasia); the former, 'socialist' approach 
was strongest in 'Southern Europe' including France (see Sassoon, 1996, for a masterly survey). The last 20 years witnessed some jumbling of these distinctions. Sweden, the archetypal reformist social democracy, saw a range of challenges to the prerogatives of capital, culminating in the proposal for wage-earner funds in the early 1980s (see Juhana Vartiainen's chapter and Pontusson, 1992b). Conversely economic orthodoxy was embraced as rapidly and wholeheartedly by the Spanish socialists as by any party of the Left in Europe (see the chapter by Albert Recio and Jordi Roca). In the early 1980s, when most of the governments analysed here came to power, the core aspirations of the Left were full employment, enhancing the welfare state and redistribution, and, finally, supply-side interventions aimed at guiding or controlling capital.

\section{(a) Full Employment}

Maintaining full employment has been the centrepiece of social democratic programmes since the 1930s as Fritz Scharpf (1991, p. 22) explains:

As long as capitalist crises could happen at any moment, whatever gains unions and social democratic parties might have achieved in the redistribution of incomes or the expansion of public services must have seemed extremely insecure. Indeed the unions had been helpless during the Great Depression of the early 1930s, as the welfare state collapsed under the burden of mass unemployment. Social democrats could thus make their reluctant peace with capitalism only if they could also hope to avoid its recurrent crises.

The achievement of full employment in the 1950s and 1960s could hardly be credited as a uniquely social democratic achievement. Germany, for example, had 1 per cent unemployment in 1960 before the Sozialdemokratische Partei Deutschlands (SPD) tasted power at the national level. The specifically social democratic dimension to full employment came to be its inclusive nature; full employment for 'core' workers (traditionally male) should not be achieved at the cost of joblessness or very low pay for other sections (women, less qualified workers, youth, the non-unionized). Sweden had 57 per cent of women participating in the labour force as early as 1968, as compared to 46 per cent in the USA or, at the other extreme, 28 per cent in the Netherlands (where the measured unemployment rate was just as low as in Sweden). The ratio of earnings of workers at the 90th and 10th percentiles (men and women) was 2.1 in Sweden, 3.3 in France, and 5.0 in USA in 1973 (OECD Employment Outlook, 1993, table 5.2). It should be noted that not all the strongly social democratic countries achieved this inclusive form of full employment. As Rowthorn (1992) showed, only the Nordic 
countries achieved both high employment and low wage dispersion; Austria, in particular, had quite an unequal wage distribution and only moderate labour-force participation (see the discussion in Alois Guger's chapter).

The fundamental problem in sustaining high employment concerns the distributional conflict, which prolonged full employment was always likely to engender. Keynes put the matter succinctly in 1943: 'the task of keeping efficiency wages [wages per unit of output] reasonably stable . . . is a political rather than an economic problem'. In the following year he wrote, 'I do not doubt that a serious problem will arise as to how wages are to be restrained when we have a combination of collective bargaining and full employment' (quoted by Winch, 1988, p. 107). 'Full employment capitalism', Kalecki said in his famous article on the political aspects of full employment, 'will, of course, have to develop new social and political institutions which will reflect the increased power of the working class. If capitalism can adjust to full employment a fundamental reform will have been incorporated in it' (1990 [1943], p. 356).

The social democratic version of Kalecki's 'fundamental reform' was coordinated wage bargaining by the trade-union movement, with centralized negotiations able to take account of the impact of wage demands on employment for the whole work-force (Calmfors and Driffill, 1988; Soskice, 1990). With the problem of containing wage pressure endemic to high employment, the solution had to be an enduring system for disciplined wage determination, rather than a government inspired incomes policy imposed in a situation of balance of payments or inflationary crisis. Employer disenchantment and differences of interest between sections of the work-force pose major difficulties with sustaining these systems, as Vartiainen and Iversen show. But no other solution to wage pressure was on offer which could hope to meet social democracy's egalitarian objectives.

Social democratic priorities for welfare, discussed below, implied a relatively high share of public spending in GDP. The expansion of government spending, even when covered by taxation, sustained demand through balanced budget multiplier effects. In addition, the larger the share of government spending, the greater the automatic stabilizer effect of budget deficits in bolstering demand in recessions. Beyond that, in the 1950s and 1960s private investment was sufficiently buoyant for additional, discretionary deficits to play only a temporary 'pump-priming' role; Scandinavian social democracies, in particular, ran budget surpluses. Full employment was never maintained by sustained budget deficits, so the collapse of full employment cannot be attributed to pressures from international capital markets to stop 
running them. ${ }^{1}$ Sustained deficits to cover current spending are a sign of weakness - the government is either incapable of levying the tax rates necessary to cover demands for public spending or is forced by weak private investment to run deficits to sustain demand. The PASOK government in Greece in the 1980s, described in the chapter by Euclid Tsakalotos, illustrates such unsustainable, populist attempts to redistribute and boost employment.

\section{(b) Equality, the Welfare State, and Redistribution}

The dogma that equality necessarily undermines economic efficiency, always disputed by the Left, has taken a terrible battering in recent econometric work on economic growth. A comprehensive survey concludes that regressions 'run over a variety of data sets and periods and with many different measures of income distribution, deliver a consistent message: initial inequality is detrimental to long-run growth' (Benabou, 1996, p. 2). Another author reported that the impact of the marginal tax rate on growth 'is positive and highly significant rather than negative as the theory would predict. This finding . . . is difficult to rationalize with most of the existing theories which emphasize the distortionary effects of government expenditure and taxation'; he also found that 'not only taxation but also redistributive expenditures are positively associated with growth' (Perotti, 1996, pp. 170-1). If the range of opportunities open to poor people is expanded their incentives to deploy their potential to best advantage will be increased. Thus reduced incentives for the rich may be outweighed by increased incentives for the poor in a 'well designed' redistribution policy (see Aghion and Howitt, 1998, ch. 9, for a review of recent theoretical analysis of this issue). If children from poor areas participate much less in higher education than their abilities would allow, then this is a failure to accumulate human capital where its return would be greatest, involving a cost to society as well as unfairness to the people concerned. So taxation of the better off to fund improvements to schools in such areas is very likely to have beneficial effects on efficiency as well as equity, and similar, if less direct effects, could be expected from much other welfare expenditure (see Richard Wilkinson's (1994) claim that more equal societies display better health throughout all the population).

${ }^{1}$ One interpretation of the full employment period (Matthews, 1968; Boltho, 1989) emphasizes private-sector confidence that demand could and would be sustained which in turn bolstered investment and rendered persistent deficits unnecessary. Such confidence rested on a number of conditions, such as adequate profits, stable industrial relations, and a predictable international environment, as well as demand-management policies. 
The socialist tradition would not confine redistributions to those which enhanced efficiency through expanding equality of opportunity (Cohen, 1997). The Left has traditionally argued for much more than a minimal safety net for those incapable of looking after themselves and, by extension, for redistribution to offset the disadvantages of those who, even with equal opportunity, suffer from a weak position in the market.

The welfare states inherited by the Left varied enormously, both in terms of resources and character. Sweden stands out as the exemplary social-democratic welfare state, promoting 'an equality of the highest standards' (Esping-Andersen, 1990, p. 27) and characterized by high replacement rates, extensive state provision of services, and maximum participation in the labour force (see the detailed discussion on the distinctive features of social democratic welfare states by Huber and Stephens).

It should be emphasized that the differences between the most and least egalitarian OECD countries have been and remain huge. In Sweden in the early 1990s, 4.9 per cent of single-parent households lived in poverty (less than half average income) compared to nearly 60 per cent in the USA and Canada (and around 30 per cent in France and Germany-OECD, 1997b, table 24). Pensioners in the UK are four times as likely to be in the worst-off 20 per cent of the population as in the bestoff 20 per cent; in France the ratio is 1.5:1 (Tsakloglou, 1996). Unexcitingsounding differences in Gini coefficients measuring income inequality mask really enormous differences in distributive patterns. Egalitarians in the more unequal countries really do have something to emulate and in the more equal countries something to fear.

\section{(c) Supply-side Intervention (or the Transformation of Capitalism)}

Full employment and consolidation and extension of the welfare state were regarded as irreversible reforms to capitalism by the social democratic revisionists of the 1950s (Crosland, 1956; Sassoon, 1996). Where there was a more or less explicit post-war settlement between capital and labour, in Sweden for example, the government pursued full employment, extended the welfare state, but guaranteed managerial prerogatives over organization of production and the allocation of capital (Gustafsson, 1995). At the other extreme, in countries such as France, the 'stabilization' which had occurred at the end of the 1940s inflicted defeats on the labour movement depriving them of the power to make anything approaching an explicit deal (see Armstrong et al., 1991); however, a similar, if less developed, pattern of welfare capitalism evolved even in the countries dominated by the Right, such as Germany. 
From around the mid-1960s two developments threatened such an 'historic compromise'. First, the labour movement grew in organizational strength and confidence as a result of the achievement and maintenance of full employment. This bred demands for further protection of conditions of employment, for an extension of union influence over corporate decision-making, and for measures to redistribute wealth, comprising a 'shift in the balance of power and wealth in favour of working people and their families', as the UK Labour Party's 1974 manifesto put it. Second, there was a belief that economic growth could be faster if government intervention could overcome coordination problems that were thought to be holding back investment.

The range of initiatives and interventions developed during the 1970s was reflected in left governments coming to power in the 1980s with programmes including:

- $\quad$ selective nationalization (France)

- planning agreements between governments and large firms (Greece)

- industry plans (Australia)

- co-determination of corporate decision-making (industrial democracy) (France, Sweden)

- wage-earner funds (Sweden)

- extension of employment rights (France)

The common idea behind these rather disparate proposals was to shift influence or even power over decision-making from private capital to government and/or workers (and, in the case of wage-earner funds and nationalization, to redistribute capital in addition). The transfer of economic power was seen as a democratic advance in and of itself; it would represent a form of economic democracy to complement the 'social' democracy achieved through full employment and the welfare state (Pontusson, 1992b). In the case of employment rights - restrictions on dismissals, and so forth-the purpose was to curtail unilateral exercise of economic power. But the justification for intervention in corporate decision-making usually rested on expected improvements in economic performance as well.

Such proposals as these faced formidable obstacles to their successful implementation. First, there was the political opposition from those whose freedom to manage and allocate capital would be circumscribed. Even if this could be surmounted, governments of the Left were obviously vulnerable to the economic effects of the uncertainty and loss of confidence involved. 'Strikes of capital' could develop quite spontaneously as owners and managers felt threatened. Second, even where 
sensible objectives could be set out, such as increasing the investment rate in order to improve productivity and trade performance, the mechanisms for inducing private firms to respond to the stimuli frequently lacked plausibility. For example, Stuart Holland, one of the foremost proponents of intervention (Holland, 1972), argued that private firms could be pressurized into higher investment by the competition from firms taken into public ownership; but lack of competition could hardly be taken as the general explanation for poor performance. It should be noted, however, that the enthusiasm for interventionism developed before the economic failures of centralized planning had become so glaring or the difficulties in contriving effective systems of enterprise governance had been seriously analysed.

\section{Context}

The starting point from which governments of the Left began to conduct economic policy in the early 1980s was far from favourable. The mid-1970s brought much slower growth rates in the OECD as a whole, combined with high inflation, squeezed profits, industrial strife, high government deficits, unstable exchange rates, weak investment, and very low levels of employer confidence. The particular economic inheritance faced by governments of the Left in the early 1980s contained many of these elements:

- unemployment was very high in Spain and rather high in France;

- inflation was particularly high in Greece and Spain and above the OECD average except in Austria;

- profitability had been squeezed more than the OECD average in France, Australia, and, especially, Greece;

- the budget deficit was particularly large in Sweden;

- investment had been growing more slowly even than the modest average OECD growth rate, except in Australia.

As explained in the chapter by Glyn and Wood, the Blair government faced a much more favourable macroeconomic pattern as the UK economy recovered from the severe recession of the early 1990s.

Developments in the international economy have always had a strong influence on the economic performance of individual capitalist economies, especially the middle-sized and smaller ones. Over the 1980s and 1990s the most significant trends across OECD countries, which influenced the capacity of social democratic governments to fulfil the aspirations of their supporters were as follows. 
(a) The Stagnation of Output Growth

GDP growth in the OECD slowed from 4.9 per cent per year over the years 1960-73, to 2.6 per cent per year from 1979 to 1989 , and 1.8 per cent per year from 1979 to 1995 . Attempting to grow faster than the average would tend to bring balance-of-payments problems as imports were sucked in. Exports could grow correspondingly faster if the real exchange rate depreciated, but this in turn would reduce real wages. Many discussions of globalization have emphasized the increasing importance of trade, but after rising in the 1970s and early 1980s there has been no further increase in the share of exports in European GDP (see Sutcliffe and Glyn, 1999). Over the 1980s and 1990s the external constraint was the slow growth of export markets rather than the growing weight of exports in the economy.

\section{(b) The Productivity Slow-down}

The growth rate of OECD labour productivity declined in line with output growth to reach 1.4 per cent per year in the 1980s and below 1 per cent per year in the 1990s. The implication is that real wages have necessarily grown slowly, constraining the political feasibility of further redistribution - in the EU real wage growth has averaged only slightly more than 1 per cent per year since 1979.

\section{(c) The Decline in Inflation}

The OECD inflation rate, measured by the GDP deflator, fell from 8.6 per cent per year over 1973-9 to 3.1 per cent in 1987, and (after a hiccup) to 2 per cent per year by the mid-1990s. The growth of international capital flows has made it more difficult to manage persistently a higher inflation rate than competitors, given the growing weight of speculation against overvalued currencies. So governments of the Left were under severe pressure to conform.

Initially, most of the social democratic governments presided over substantial currency depreciations. During the first 4 years in government effective exchange rates fell by between about 18 per cent (Sweden and France) and 38 per cent (Greece and Australia); only Austria (and the UK more than a decade later) bucked this pattern. By the early 1990s all the governments of the Left had abandoned depreciation and opted for hard-currency policies. Since Mitterrand's programme had been the most radical, his conversion in 1983 to the franc fort policy was the most dramatic, as discussed in Frédéric Lordon's chapter. Just as significant was the falling into line of the Swedish Social Democrats in 1991 with their budget statement that 
in the longer run it is not possible to safeguard employment in an economy which has a higher inflation rate than the surrounding world. In order to protect employment and prosperity economic policies in the next few years ... will have to aim for a permanent reduction in inflation. This task must take priority over all other aims and ambitions. (quoted by Notermans, 1993)

Coordinated wage bargaining could bring the inflation rate down in line with OECD-wide trends-disinflation by agreement rather than by the fear of unemployment. But coordinated reductions in the inflation rate are tricky as they require systematic acceptance of wage increases below the going rate of inflation plus productivity growth. Moreover, maintaining a very low rate of inflation once achieved may bring additional problems for coordinated bargaining systems, as Juhana Vartiainen explains. The Swedish system actually involved a number of levels of bargaining (centre, industry, firm), and a very low inflation rate compromises the ability of negotiators at each level of the wage-bargaining process to deliver money-wage increases to their constituencies. The implication is that, even with a coordinated system, higher unemployment may be required to impose necessary real wage restraint if the inflation rate is very low (see Akerlof et al., 1996, for an alternative explanation of why the non-accelerating inflation rate of unemployment (NAIRU) may be higher at low inflation rates). Nevertheless Torben Iversen's chapter argues that the alternative of accommodating inflation with periodic devaluations brings worse results in the end.

\section{(d) Financial Deregulation and Domestic Instability}

Violent swings in demand swamp the capacity of any bargaining system to maintain high employment. In the 1980s financial deregulation unleashed a series of destructive consumer booms and slumps. Surprisingly perhaps, governments of the Left did not escape these pressures. Consumer booms were as strong in Sweden (fall of 7 percentage points in the savings ratio between 1985 and 1988) or France (fall of 6 percentage points between 1983 and 1987) as in the notorious case of the Lawson boom in the UK (fall of 7 percentage points between 1983 and 1988) and considerable also in Australia, Spain, and New Zealand. Austria stands out, again, with stable or even rising savings at the end of the 1980s. The reaction to the consumer boom, in the form of rising savings ratios as policy was tightened, was even fiercer in Sweden than in the UK (a rise of 13 points between 1989 and 1993 as compared to 8 points in the UK). This was the immediate factor behind the disastrous rise in Swedish unemployment (see Calmfors, 1993). No plausible degree of wage flexibility could offset a demand 'shock' of this magnitude. 
Perhaps an expansion of consumer credit was especially seductive in a context where take-home pay had been squeezed over an extended period. But such macroeconomic mismanagement seriously compounded the underlying problems in the bargaining system in Sweden and John Quiggin makes a similar case against Labor in Australia. Precipitate deregulation of domestic financial markets was more a question of aping international fashions than an inevitable consequence of globalization. Many countries avoided such excesses - Germany, for example. The obsessive focus on macroeconomic stability of the Blair government can be traced to these damaging experiences.

\section{(e) Declining Demand for the Unskilled}

It was pointed out earlier that the Left has believed, or at least come to believe, in an inclusive pattern of full employment. The past two decades have seen a strong shift in the demand for labour away from those with few qualifications; in the race between declining demand and declining supply the former has emerged the stronger (Machin and Van Reenen, 1998). In most countries, either their relative pay, or their chances of being in work, and frequently both, have worsened considerably in the 1980s and 1990s (Glyn and Salverda, 2000). Again globalization has been in the dock. However, the evidence suggests that North-South trade has so far been a relatively minor contributor to this trend; more significant influences have been the bias of technical progress and institutional changes, including the weakening of trade unions which had been particularly effective in defending the jobs and pay of less qualified industrial workers (Howell, 2000). Although high employment overall appears to bring disproportionately great benefits to the least qualified, it may be insufficient to ensure the position of the least qualified, and deliberate policies to boost demand for their labour may very well be necessary (such as in-work benefits, labour subsidies, or the expansion of public services targeted regionally on the areas of lowest employment-see Iversen's discussion of the dilemmas posed over how to increase demand for the less qualified). Such measures in turn require higher taxation. Thus the possibility of an egalitarian pattern for full employment is closely linked to the broader issue of welfare and redistribution.

\section{(f) Taxation and the Welfare State}

There is a general presumption that it became increasingly difficult during the 1980s to raise the taxation necessary to fund further increases in the share of government spending. One common explanation is that globalization limits taxation, especially taxes on profits and 
interest income, as countries compete for direct investment and to retain portfolio funds. The EU's Expert Committee (CEC, 1992) did find less variability of tax systems across member countries in the 1980s, but a decline in corporation tax rates was balanced by cuts in the value of investment incentives so that the overall impact of corporation tax did not decline. Top rates of tax were reduced in the 1980s in all the countries considered in this issue (OECD, 1989, table 5.11). However, taxes were cut on relatively less mobile labour as well as on unearned income. Contagion of ideas about incentives may well have been more important than tax competition between countries. Taxation of capital has been rising only a bit slower than taxation of labour over the past 20 years (Rodrick, 1997). Squeezing business investment, as in the profits crisis of the 1970s, or running balance-of-payments deficits which provide resources in excess of current production, cannot support a sustainable redistribution, as the Greek experience in the 1980s, recounted by Euclid Tsakalotos, shows very clearly. In the longer term, wage and salary earners have to pay for a large part of redistribution (though the taxation may be more or less progressive).

A more significant constraint on redistribution than overseas tax competition has been the slow-down in the growth of productivity and, therefore, living standards. An example from Sweden illustrates this. At the end of the golden age of growth (1965-73), consumption out of earned income per worker was growing about 1.2 per cent per year. This was 2.6 per cent per year slower than labour productivity growth in the market sector, as increased taxation was required to finance growing transfer payments and an expansion of state services. Over the subsequent 6 years, consumption out of earned income per worker fell by 1.7 per cent per year (Glyn, 1992). More than half of this slow-down in consumption growth (as compared to the previous period) reflects slower productivity growth, and less than half the greater weight of redistribution as transfers grew more rapidly. A given increase in the share of public spending and taxation in GDP may be far less burdensome if it occurs when productivity growth is rising rapidly, since then it is the growth rate, rather than the absolute level of consumption, which is held back. So the 1960s were the ideal time politically for a radical extension of the welfare state; for the latecomers in Southern Europe the 1980s, with much slower productivity growth, made matters much more difficult.

A further trend militating against redistribution is raised by Vandenbroucke (1998):

to the extent that skill has become more important as an explanatory factor of quite visible wage inequalities such inequalities come to have more of a 
biographical character: they seem to be more related to personal history and qualifications than to class as traditionally understood.

Greater differentiation of pay, deliberately fostered as a strategy to increase incentives by management, may have had the unintended impact at the social level of justifying market outcomes. In similar vein, Przeworski suggests that increasing differentiation of the risks faced by individuals encourages private insurance catering for specific risks rather than much broader pooling of risks through state insurance. Such trends may have squeezed support for an egalitarianism going beyond a narrow conception of equality of opportunity.

This brief overview shows that the circumstances under which governments of the Left were attempting to meet the aspirations of their supporters were far from ideal. General trends within the world economy-growth slow-down, declining demand for less qualified workers, the epidemic of neo-liberal ideas in response to these problems - seem to have been more significant than globalization in the sense of increasing openness, although greater capital mobility undoubtedly played an important role in enforcing inflation convergence. The next section summarizes how the Left fared.

\section{The Record}

The chapters which follow give a rich picture of the diverse circumstances faced by, and the uneven results achieved by the social democratic governments surveyed; what follows is a bald overview. ${ }^{2}$

\section{(a) The Employment Record}

Employment was accorded such centrality by the Left that it is reasonable to take it as the key indicator of macroeconomic success.

Sweden's very favourable employment record during the period of Social Democrat rule in the 1980s is misleading. The collapse of its strategy meant that by 1994 the employment rate had fallen by 9 percentage points. If the Swedish record up to 1990 showed that unemployment could be kept at very low levels, despite the internal and external pressures, the subsequent collapse of employment showed how vulnerable high employment had become. Australia's record appears better; the rise in unemployment was small and both the employment rates and female participation rose at a time when population of working age was growing very fast. Moreover, this was

${ }^{2}$ Detailed tables with supporting data are given in Glyn (1998a). 
achieved without much rise in wage inequality; the weakening of the Accord allowed wage inequality to increase in the early 1990s, but there was little change over the period as a whole. Unfortunately, unemployment stayed high as the number of jobs created still fell short of those needed to reduce it. The pattern for Austria is somewhat similar, except that unemployment remained relatively low. A very large rise in women's participation rather belies Austria's reputation for a low degree of inclusiveness; there was a moderate rise in earnings inequality, however. For the remainder of the countries the employment record was very poor - substantial rises in unemployment and/or falls in employment. The rapid increases in women's participation in Spain is rather misleading in that female unemployment rose nearly as much. As Albert Recio and Jordi Roca emphasize, the employment problem was especially daunting in Spain, where rapid decline in agriculture and restructuring of industry coincided with this surge in women's participation. In France, the minimum wage retained its value in relation to average earnings in contrast to the decline in Greece and Spain and most OECD countries (OECD, 1997a, chart 1.2) and wage dispersion (although rather high) did not grow. The one really sharp rise in pay dispersion was in New Zealand.

As discussed earlier, governments of the Left found little alternative but to bring inflation down in line with other countries. How successful were they in minimizing the unemployment cost? Reducing inflation by as much as the OECD average, while suffering a lesser rise in unemployment, would constitute success of a sort. Most of the left governments presided over noticeably larger increases in unemployment than the average for the OECD over the same period. Inflation was typically reduced by more than the average fall in OECD countries, but from higher starting points. However, the disinflation exacted a heavy toll in terms of lost jobs. France exemplifies this pattern; over the period 1980-93, unemployment rose 3.8 per cent more than the OECD average, while the fall in the inflation rate was 4.1 per cent more. Only Austria stands out as having resisted the tide of rising unemployment, with the Left benefiting from the low inflation it had inherited from the 1970s.

Austria also ranks consistently as having the most centralized and coordinated wage-bargaining structures (see OECD, 1997a). In Sweden, however, the centralization and coordination of wage-bargaining was decreasing, which Vartiainen blames partly on the unrealistically egalitarian ambitions of the unions. The Australian Accord, an unexpected corporatist development in reaction to the problems faced by the earlier Whitlam Labor government in the mid-1970s (Archer, 1992), was widely regarded as rather effective for most of the 1980s. It atrophied from the end of the 1980s, as centralization of bargaining 
declined. Recio and Roca describe how the attempts at a social pact in Spain soon broke down, culminating in a successful general strike against the government's welfare reforms. In Greece, Tsakalotos concludes that the trade-union movement was too divided along party lines and without sufficient independence from the state, for a corporatist solution to the problem of wage-bargaining ever to have had much chance of enduring success. The histories recounted in this volume underline how difficult coordinated wage bargaining is to sustain. However, the Left has no alternative proposal for the containment of distributive conflict (see Boyer et al., 1994), and the hostility of the Blair government, for example, towards anything which smacks of corporatism may prove difficult to sustain if high employment is maintained.

\section{(b) Equality and the Welfare State}

Sweden had the most equal distribution of household income of all the OECD countries at the beginning of the 1980s, with a household 10 per cent from the top having 2.45 times as much income as one 10 per cent from the bottom (Atkinson et al., 1995, ch. 4). Austria (90/10 ratio around 3), New Zealand and France (3.5), and Australia and Spain (4 and slightly over) span the central and lower range of the inequality ranking (the ratio in the USA at the time was nearly 5). Income inequality rose very sharply under Labor in New Zealand. In Australia, Sweden (and probably Austria) there were smaller increases in inequality, similar to the rise in the USA (Atkinson et al., 1995, ch. 5; Gottschalk and Smeeding, 1997, Appendix table B; OECD, 1997b). In France, the distribution of income was very stable (true also of Germany, Italy, the Netherlands, and Canada). In Spain-according to the analysis reported by Recio and Roca-and Greece, there seem to have been modest declines in inequality (Tsakloglou, 1996).

Huber and Stephens conclude that cuts in welfare entitlements and services have generally been modest as the popularity of the welfare state has made attempting deep cuts very unpopular. They suggest that differences between Left and Right in this respect have diminished (with the Left becoming less willing to raise taxation).

\section{(c) Supply-side Interventions}

Some of the proposals for supply-side intervention discussed earlier were implemented in full, but in circumstances which seemed to dictate an abandonment of original objectives (nationalization in France); others were watered down (wage-earner funds in Sweden); and some allowed to atrophy (planning agreements in Greece). There has been relatively little legacy from all this effort. Instead, the main thrust of 
policy shifted to the restoration of profitability as the basic condition for securing an investment recovery. By the end of the 1980s there had been a rather dramatic recovery of manufacturing profitability in France, Australia, and Sweden (7-12 percentage point increase in the profit share of value added - see Glyn, 1997a), with Greece, exceptionally, showing a fall. Investment rose rapidly in the later 1980s but from the very low level reached after a decade of stagnation. Only in Australia and Sweden was the share of investment in GDP higher at the end of the 1980s boom than during 1974-9, and in those two countries it fell by 4-5 per cent of GDP in the ensuing recessions.

Moreover, the brief burst of investment at the end of the 1980s was concentrated in the service sectors, suggesting that the Left's focus on the manufacturing sector, because of its significance for international trade, had little impact, or at least was swamped by other influences. Here again, financial deregulation, sharply criticized by Quiggin for its baneful influence in Australia, probably played an important part.

The SPD Chancellor, Helmut Schmidt, had made the case for relying on profitability in 1976: 'The profits of enterprises today are the investments of tomorrow and the investments of tomorrow are the employment of the day after' (quoted by Bhadhuri, 1993). Having done all that could be expected of them in terms of ensuring profitability, social democrats discovered that it was far from being a sufficient condition for a high level, and appropriate distribution of investment.

Nevertheless, confidence on the left that governments and unions could interfere purposefully to reshape the pattern of production evaporated. Ensuring that the playing field slopes in the appropriate direction (infrastructure, education, corporate taxation) is seen as a legitimate, even necessary role for the government, but giving directions on tactics, let alone picking the team, is decidedly not. Most of the governments discussed in this volume ended up by accepting the privatization of state industry and assets.

While the economic legacy of the attempts by the labour movement in the 1970s and early 1980s to constrain the power of capital has been meagre indeed, the political legacy has been extremely important. The prominent Swedish economist Erik Lundberg wrote in 1985, 'The fall of the Swedish model is, at bottom, a political development. The present political crisis [his emphasis], which has involved intense confrontation between socialist and non-socialist parties, since the middle seventies, has created a stage of uncertainty and bewilderment' (1985, pp. 31-2). Assar Lindbeck (1997, p. 1277) put it thus:

The unions' ambitions to gain power peaked in the second half of the 1970s, when they proposed the creation of union controlled, tax financed wage- 
earner funds designed to take over the bulk of ownership of Swedish corporations on the stock market. The proposal may, more generally, be seen as a unilateral cancellation of the implicit cooperative contract between labor and capital.

Lindbeck goes on to refer to the subsequent employers' offensive which was described in graphic terms by Robert Taylor (Financial Times, 8 November 1990) under the headline 'Business plans five-year campaign to end Swedish economic model'. He reported that this was a plan to 'transform social-democratic Sweden into a robust freemarket economy', aiming to 'destroy the vestiges of the famed Swedish economic model, with its collectivist values of equality and solidarity'.

If the proposals from social democracy to control capital can be seen as flowing from the extended period of high employment, then the political offensive by the employers bears out Kalecki's remarkable prediction in 1943:

the maintenance [Kalecki's emphasis] of full employment would give new impetus to the opposition of business leaders. Indeed, under a regime of permanent full employment, the 'sack' would cease to play its role as a disciplinary measure. The social position of the boss would be undermined, and the self-assurance and class consciousness of the working class would grow. Strikes for wage increases and improvements in conditions of work would create political tensions. ... 'discipline in the factories' and 'political stability' are more appreciated than profits by business leaders. Their class instinct tells them that lasting full employment is unsound from their point of view, and that unemployment is an integral part of the 'normal' capitalist system. (1990 [1943], p. 351)

The one respect in which the labour movement's offensive had a lasting impact on the 'supply side' of the economy concerned employment rights. In many countries in the 1970s and early 1980s employment rights were strengthened or extended (to part-time workers, for example). Coverage of collective bargaining agreements was generally maintained, and in France it increased to 95 per cent (even though union membership declined to 9 per cent). ${ }^{3}$ While less threatening than planning agreements, let alone nationalization, extension of employment rights did represent a constraint on managerial prerogatives, limiting 'labour-market flexibility' from the point of view of employers. The OECD has been engaged in a militant campaign to reverse these developments. Ironically, in Spain, limitations on dismissal were inher-

${ }^{3}$ Sweden and Spain, with union membership at 80 per cent and 9 per cent of the work-force in 1980 respectively were exceptional in recording increases in membership (about 10 per cent of the work-force in each case) over the 1980s and early 1990s (OECD, 1997a, table 3.3). 
ited from the Franco period. Recio and Roca dispute the common perception that these were unreasonably draconian and take the Partido Socialista Obrero Español (PSOE) government to task for accepting the widespread use of temporary contracts in order to circumvent them. ${ }^{4}$

Shifts in the state of relations between capital and labour are not susceptible of precise measurement, but comparing share prices with average wages gives some indication of the balance of advantage. Between 1973 and the Left's accession to power, stock-market prices fell by one-half compared to wages in several countries, and much more in Spain. There was a general recovery of share prices under the left governments under review here, with the exception of Greece and New Zealand. Relative to wages, share prices rose by about one-half in Austria and Spain (similar to the rise in Germany over the period 198095), nearly doubled in France and Australia (as in the UK), and tripled in Sweden (matching the rise in the USA). Despite the restoration of profitability and confidence the investment response remained anaemic throughout the countries surveyed here.

\section{Conclusions}

This introduction has examined the record of left governments during the 1980s and 1990s in the light of their aspirations to maintain or achieve full employment, to ensure an egalitarian distribution of welfare, and to enhance democratic control over the allocation of capital and the organization of work places.

Macroeconomic starting points were unpromising; inflation was high and profits squeezed in many countries and there was a need to cope with rapid structural change (run-down in agriculture in Southern Europe, increase in women's participation). The context was difficultslow growth throughout the OECD and the pressures favouring disinflationary policies. There were some bright spots in the employment record. During the 1980s employment grew very rapidly in Australia, including a major increase in women's participation, and without an increase in wage inequality; unemployment stayed very low in Sweden, and in Austria high employment was preserved and made more inclusive as women's participation rose. But elsewhere unemployment rose rapidly and/or employment rates fell, and in New Zealand wage inequality shot up as well. Overall, the cost of reducing

${ }^{4}$ The failure to find a robust effect of more employment protection on unemployment (see Nickell,1997; OECD, 1999; Blanchard and Wolfers, 2000) suggests that its impact is dependent on other features of the economy. 
inflation from higher inherited rates than the OECD average was a greater increase in unemployment than in the OECD as a whole. Given the priority accorded to employment, this record must be reckoned as extremely disappointing.

The context of slow productivity growth was unfavourable for an extension of welfare spending and redistribution, which would squeeze take-home pay, and the record of left governments was mixed. Important expansions of welfare were achieved in those countries with the weakest welfare states. New Zealand is really the anomalous case, with inequality rising as fast during the short period in office of Labor as in the UK under Thatcher. In Australia, Sweden (and probably Austria) inequality rose as fast as the rise in the USA (though from very much less unequal starting points). Income inequality fell somewhat in Greece and Spain, but this seems typical of Southern European countries, where structural change was rapid. In France, income inequality was stable (with a heavy cost in public spending) but non-socialist governments brought a similar outcome in Germany and Canada, for example. Perhaps the best summary is that the range of outcomes for the group of countries here was not much different from that of OECD countries as a whole; again social democrats might have expected better.

The measures to plan, control, widen the ownership of, or nationalize private firms, so prominent in the discussions of the 1970s on the left, have sunk with little trace, except for a legacy of business hostility towards the whole social democratic model which governments of the Left, such as UK Labour, have been at pain to dispel. A high level of investment implies that demand can be kept high without budget deficits and that the capital stock will increase rapidly and provide the resources to accommodate wage pressure and fund improvements in the welfare state. Having abandoned the often half-hearted attempts to pressurize private capital into such investment, governments of the Left had little option but to rely on a restoration of profitability to do the trick. Wage restraint was indeed achieved, through rising unemployment or coordinated bargaining or both, but the investment response was erratic and especially weak in manufacturing which is still of central importance for trade and for jobs. Here again the experience of countries under social democratic rule was not untypical of OECD countries (Glyn, 1997a). Capital did not deliver high investment in return for high profits, but social democratic governments have seen no alternative but to redouble their efforts to create even more favourable conditions.

An optimistic interpretation of this experience would emphasize that the circumstances of the 1980s and 1990s-slow growth, the pressure for disinflation, excessively tight macroeconomic policy in 
Europe, private investment still hesitant after the previous decades of instability - were extremely unfavourable for governments of the Left. Coordinated bargaining, though subject to many pressures and vulnerable to ill-judged macroeconomic policy, survives as an alternative to unemployment as a regulator of social conflict, and one whose relevance will grow if the more favourable macroeconomic conditions persist and unemployment rates decline. With the exception of New Zealand, wholesale capitulation to conservative economic policies was avoided by governments of the Left and retreats on income inequality and welfare-state provision have been limited. The generalized claim that equality involves too high a cost in terms of efficiency has been shown to be ill-founded and neo-liberalism is on the defensive against growing demands for financial and environmental regulation. On the basis of a renewed appeal to social solidarity, employment can be raised, employment rights extended, environmental concerns addressed, and egalitarian shifts in the distribution of welfare preserved or extended. However, regaining such a position requires above all that the costs (wage restraint and tax increases) are openly canvassed and campaigned for, a task that social democracy has clearly ducked for the present. If higher employment could be sustained for an extended period, however, then bargaining power would tilt back towards labour and the issue of democratizing ownership and control in the economy, submerged in the 1980s and 1990s, would surely return to revitalize the Left's agenda.

An alternative interpretation, closer to the position of a majority of the contributors to this volume, would see governments of the Left succumbing to remorseless pressure, both ideological and from the economic constraints they faced, to accept orthodox policies - priority to inflation control, limitation of overall tax burdens, labour-market deregulation. The Left can still intervene in valuable ways to stem the tide of rising inequality-more in-work benefits for the low-paid, protection of the most vulnerable when welfare states are reformed, targeting the extremes of inequality of opportunity which are obviously economically inefficient. However valuable in themselves, these are strictly limited objectives and if they really represent the limits to social democracy's vision, then as Perry Anderson put it: 'what kind of movement will it change into?' (1994, p. 16). 


\title{
How Many Ways Can Be Third?
}

\author{
ADAM PRZEWORSKI*
}

\section{Introduction}

Does social democracy make a difference? It is only natural to expect that most of the time it would not. Once particular policies have been tested, most parties will keep offering and implementing these policies regardless of their ideological stripes. The real question is whose policies these are: who leads and who follows?

During the past one hundred years, social democrats repeatedly discovered 'third ways'. Each of these new ways was motivated by a claim that social democracy faced new conditions, and each new strategy was portrayed as the best given the new constraints and opportunities. Several new strategies were path-breaking ideologically and ingenious practically. But third ways do not lead to the first-best. If social democrats sought new ways, it is not only because they believed that the old ways would not bring them closer to their goals, but also because some goals were discovered to be infeasible given the constraints and some were found no longer attractive for other, often electoral, reasons. In any case, as new strategies were invented, some goals were abandoned. Most prominent among them is something that used to be called 'socialism'.

Hence, the achievements and the failures of social democrats cannot be judged by their own historical goals. But if it is not by their own goals, how else can one evaluate social democratic performance? One manner, represented by this volume and innumerable similar studies, is to examine their recent record in office and compare it to that of their opponents. This is a sensible way: as a voter, I want to use my vote to

* New York University.

I appreciate comments by Luiz Carlos Bresser Pereira, Andrew Glyn, Gösta Esping-Andersen, Stephen Holmes, Fernando Limongi, Bernard Manin, Covadonga Meseguer Yebra, José Maria Maravall, Joanne Fox-Przeworski, Molly Przeworski, Kathleen Schwartman, Ignacio Sanchez-Cuenca, and Michael Wallerstein. 
select the government that is more likely to avoid war, increase incomes, control inflation, reduce unemployment, keep streets safe, protect health, educate children, win the World Cup, and keep otherwise out of my life. Hence, I do want to know whether social democrats are better at reaching these objectives than their electoral opponents.

This criterion assumes that the objectives and the policies pursued by any one government are independent of those followed by other governments. Yet the newly elected bourgeois government may pursue the same policies as its social democratic predecessor, or vice versa. For example, according to Iversen in this volume, the Danish centre-right majority government embarked between 1968 and 1971 'on an ambitious "spend-and-tax" policy that dwarfed anything the social democrats had done in the past'. In turn, Blair's Labour government in the UK adopted the policies of its Conservative predecessors. ${ }^{1}$ In each case, two successive governments differed little in their policies, but the policies are quite different: in the Danish case bourgeois governments pursued social democratic policies, while in the British case the Labour government follows neo-liberal ones. ${ }^{2}$ Presumably, in both cases the second government was persuaded that the policies of the first are successful, at least in the sense that voters would like these policies or their outcomes. If indeed, 'the ultimate test of a political movement is whether it can impose its own preferences on the majority of the electorate' (Vartainen, this volume, p. 23), then it makes a difference whether a government induces others to follow its policies even when it is defeated.

Thus differences owing to partisan control cannot be read exclusively from comparing the policies and outcomes of social democratic as compared to bourgeois governments at any moment. To identify the difference due to social democracy, one must decompose policy trends into two components: the changes of 'policy regimes' over time and the differences between social democratic and bourgeois parties at each time. For suppose that, at some time, social democrats and their

1 According to Giddens (1998, p. ix), confronting Thatcher's revolution, 'The Labour Party and its intellectual sympathizers first of all responded largely by reaffirming old left views. The electoral setbacks the party suffered for doing so, however, necessarily stimulated a new orientation.' José Maria Aznar, the right-wing prime minister of Spain, claimed that the Blair-Schroeder declaration of 9 June 1999 was distilled from a letter he sent to Blair (El Pais, Madrid, 12 June 1999).

${ }^{2}$ Note that it may also be the case that a social democratic government initiates right-wing policies which are followed by a bourgeois one. According to Quiggin (this volume, p. 80), 'the shift to the right [by Conservative governments in Australia] is simply an extension of policies initiated by labour governments in the 1980s', even if these were in turn initiated by Margaret Thatcher in Great Britain. 
opponents follow exactly the same policies: the question remains whose policies these are. What matters is who sets the tone: who defines the goals, who has more persuasive theories, who has better examples to demonstrate, who can reduce the space for the opponent.

The history of policies may thus have the following dynamic. A government comes to office, makes a major successful policy innovation, and develops a story about the secret of its success. The opposition party campaigns in elections criticizing the incumbent, but everyone knows that, if elected, the new government would follow the same policy. The difference between the two parties is so small that voters base their decisions on accidental issues - a scandal, personalities, a television debate - and at one time the incumbent loses. The victorious party follows the policies of its predecessor. Partisan control alternates without policies changing until, at some time, someone, the right or the left, introduces a major policy innovation, this policy is successful, and the cycle repeats itself.

Obviously, not all major policy innovations are successful; some are unmitigated disasters. If this model is correct, Bayesian learning must drive the policy process. ${ }^{3}$ Clearly, Bayesian learning cannot explain the particular form of the policy innovations: these are based either on blueprints or on powerful intuitions. But once a policy is around, and its effects are manifest, other governments, whether in the same or in other countries, update their beliefs about the relative efficacy of different policies, and eventually abandon those that failed and pursue those that are successful. I am not claiming that this adjustment is instantaneous: Lordon (this volume, p. 119) observes that while 'désinflation compétitive appears as the outcome of a painful learning process imposed by external constraints . . . it took almost 10 years for public power to acknowledge this contradiction and to envisage a radical transformation of the economic policy regime'. But, sooner or later, they learn: as Stiglitz (1999a) puts it, 'We are all Bayesians.'

We should thus observe temporary equilibria in which policies are similar regardless of who is in office, punctuated by major policy innovations that temporarily distinguish parties, and followed again by convergence to a new equilibrium in which policies do not differ. I will refer to these equilibria, in which policies differ little across partisan stripes, as 'policy regimes'.

While such a model could be tested empirically, a statistical analysis will not illuminate the question which I find more interesting, namely, the qualitative evolution of the dominant policy regimes and their impact on social democracy. Hence, I adopt a different tack. I want to

${ }^{3}$ On Bayesian learning about policies, see Meseguer Yebra (1999). 
know which goals, values, and policies were forsaken by social democrats, whether or not it was inevitable that they would be forsaken, and if it was not inevitable, whether or not it was wise to give them up. But I do not wish to shy away from the question as it now stands: can social democracy make a difference? These questions organize the chapter. I begin by offering a stylized history of 'social democracy'. Then I characterize the successive policy regimes and discuss how they change. Finally, I examine the choices facing social democrats today.

\section{A Stylized History}

At the risk of drawing a caricature, let me sketch a stylized history of social democracy. Clearly, no student of a particular party will recognize it here. Indeed, the Swedish SAP, the Spanish PSOE, and the Greek PASOK have so little in common that one can wonder whether the question as to whether 'social democracy' makes a difference is well formulated. Hence, first, we need to clear some methodological underbrush.

One way to understand this question is to ask if the tenure in office by SAP made a difference in Sweden, by PSOE in Spain, or by PASOK in Greece, given the conditions of each country at each time, and then list or average the answers. Formulated in this manner, the question is about counterfactuals: what would have had happened in Spain if PSOE had lost in 1982? More generally, if social democrats hold office under different conditions from their bourgeois opponents, then we have to isolate the effect of partisan control from that of these conditions. Methods for doing this exist, ${ }^{4}$ but again this is not the approach I adopt here.

An alternative is to construct a stylized history of 'social democracy'. This approach hurls itself against several difficulties. One is that the degree of coordination among the social democratic parties was not the same at various times: in 1902, when the French SFIO considered entering into a bourgeois government, the Socialist International polled leaders of all parties to decide whether this was a correct strategy. Second, during each period some parties were perceived as paradigmatically 'social democratic', so that any stylized picture will be drawn disproportionately from their experience. Yet a stylized history makes sense if, in spite of all the differences in the timing (SPD rejected Marxism in 1959, PSOE in 1979) and particular policies (say Rehn-

\footnotetext{
${ }^{4}$ On selection bias and ways of coping with it, see Heckman $(1979,1988)$.
} 
Meidner Plan versus Austro-Keynesianism), the sequence of policy regimes was similar in different countries.

I believe it was: namely, that the long-term historical evolution of 'social democracy' proceeded from revolution to reformism to remedialism. ${ }^{5}$ The question remains is whether it will end in resignation.

\section{Reformism}

In 1891 the goal was clear: it was socialism understood as the public ownership of the means of production. Whatever else socialists dreamt about would come of itself, once the means of production were socialized: material progress would lead to universal satisfaction of needs, classes and their conflict would disappear, cooperation would become the mode of social life; wars, prejudice, alcoholism, and prostitution would all vanish. This is not a caricature; at least not of the SPD in the 1890s. Only one revolution was needed - nationalization of the means of production-since this revolution would solve all problems for everyone. The internationalism of the movement had both a finalistic and a strategic aspect: socialism was the goal of humanity and it could be reached only by a concerted action of workers in all countries.

The strategy, however, was controversial from the onset. The question was whether an act of violence was necessary. In one analysis, with the advent of universal suffrage, socialists no longer needed stones, just ballots. All that was needed was to wait for the working class to grow inexorably in numbers, until workers would become the numerical majority. Moreover, electoral competition based on extensive suffrage opened to socialists the possibility of aiming at intermediate, partial goals. Even if nationalization of the means of production would solve all the problems, some urgent problems could be solved without it. Thus, social democrats began to compose lists of immediate demands: education and justice were prominent among them. Yet in another analysis, violence was inevitable because the bourgeoisie would never consent peacefully to the expropriation: the revolution had to be violent, whether anyone wanted it to be or not and thus socialists should prepare for it rather than play electoral, bourgeois games.

${ }^{5}$ Since this stylized history is a temporal extension of my (1985) book, I do not cite the evidence and the sources. 
The First World War surprised socialists in four ways. First, workers fought against workers. Second, revolution occurred in the least expected country, quickly turned violent, and continued to be repressive. Third, not only did the bourgeoisie not rise in arms against the electoral progress of socialists but, first in Denmark in 1916, and then in Sweden, Norway, the United Kingdom, and France, socialists were either invited to form minority governments or to join multi-party coalitions. Finally, having grown spectacularly until 1914, the electoral support for socialists stagnated short of a majority.

The consequences of these events were profound. They led to a split that separated social democrats from communists. 'Social Democracy' was born of this split. It was 'the third way': neither communism nor capitalism. While Lenin exhorted the Hungarian workers that democracy is just a form of bourgeois dictatorship, by 1919 several Western European social democratic parties eyed electoral victories. Moreover, the separation of paths between the Soviet Union and the West reinforced the damage to internationalism caused in August 1914. Elections were a national institution; workers had national sentiments; appeals to nation won votes. Internationalism became a strategic appeal of the Soviet Union, an instrument for penetrating Western European parties.

Rejecting the Soviet example long before the massive atrocities of the communist regime would become known, social democrats resolutely embraced the democratic road to socialism. This road was to lead to socialism, still understood in terms of 1891: the only economic programme social democrats had was nationalization. But this programme could not be implemented by parties that did not enjoy electoral majorities. Hence, when they formed minority governments or took part in coalitions, social democrats did not know what to do. Moreover, the double threat of communism and fascism led to a clear differentiation of the issue space into two dimensions: economic and political. ${ }^{6}$ To defend democracy, social democrats had to compromise on economic issues. $^{7}$

Not being able to implement their programme, social democrats did what they could for their working-class constituency. Specifically, given the high rates of unemployment that punctuated the inter-war period, social democrats focused on two immediate criteria for their

6 The Chilean coup was an important lesson in Italy, while the defence of democracy was the primary concern of social democrats in Spain after 1977.

${ }^{7}$ For an argument that, under some plausible assumptions concerning income distribution, the left party will moderate on the economic dimension when facing competition in two-dimensional issue space, see Roemer (forthcoming). 
actions, namely, employment and insurance. Such measures, even if they favoured workers, were not new: they continued the tradition of reforms of Bismarck, Disraeli, or Giolitti. When in office, social democrats behaved like other parties: with some distributional bias towards their constituency but full of respect for the golden principles of the balanced budget, deflationary anti-crisis policies, gold standard, etc. As for nationalization, they did what governments do with awkward issues: formed study commissions.

The movement continued to pursue a goal, which was socialism, but that goal was relegated to an ill-defined future. Social democrats' embrace of democracy was not just a commitment to abide by its rules and to defend it against enemies, but a constraint on policies parties could pursue in office. Only those policies could be implemented that enjoyed majority support and did not threaten democracy; other projects were deemed 'premature' by the democratic pacemaker. Thus, reformism was an adaptation to political constraints, even if these were self-imposed. The ultimate goals could not be reached immediately, but they could be advanced gradually. And since each reform was a step forward, the steps would one day lead to the realization of the ultimate goals.

For the reformist strategy to work it would have been necessary that (i) the reforms are irreversible, (ii) they are cumulative, (iii) they lead in the same direction. Social democrats realized that some policies they had to pursue only administered the capitalist economy. But other policies would be transformative. Social democrats would introduce reforms once in office; if they made mistakes by advancing too far ahead of the electorate, they would lose, but this would not be a disaster since the opponents would not reverse them; once they won again, social democrats would introduce new reforms; and thus the process would continue until, in Jaures's allegory, the invisible line of the equator would have been crossed, recognized by sailors only from the song of birds and the warmth of winds.

Hence, even if, once in office, social democrats pursued policies that deviated little from those of their bourgeois opponents, they could claim that they were leading the society to a different future.

\section{Remedialism ${ }^{8}$}

As employment and equality became the goals, nationalization of the means of production was no longer necessary. Public ownership of

8 The term is Robert Dahl's. 
some banks, perhaps of transport, or some strategic firms may facilitate government control over the economy, but nationalization is just one among many policy instruments, not a panacea. Capitalist economies could be controlled without state ownership: business cycles could be avoided, or at least attenuated, and unemployment with them; income distribution could be corrected; adversities could be insured. This was the great discovery of social democrats, first in Sweden in the 1930s and then elsewhere.

Whether this answer had a directly social democratic (Wicksell) or a liberal (Keynes) inspiration, it constituted a policy revolution. Moreover, it suited social democrats particularly well: since economic stimulation could be achieved by transferring incomes to workers, the narrow interest of their constituency was the same as the interest of the entire society, so that Léon Blum could say that 'a better distribution ... would revive production at the same time that it would satisfy justice' (cited in Weil-Raynal, 1956, p. 54).

A full reconciliation of social democrats with capitalism came in the 1950s. In the context of the Cold War, with the experience of fascism, wholesale nationalization would have been politically destabilizing. And capitalist economies functioned well in many aspects. Hence, nationalization of the means of production, 'socialism' in the Marxist sense, was at best unnecessary. 'Socialism' was not some kind of an illusive future but hic et nunc the opportunity for everyone to realize his or her potential and the security that no one would be abandoned to ill fate.

If productive resources are to remain in private hands, what is the proper role of the state? The answer, not specific to social democrats, was that in many respects competition was a better allocation mechanism than command. But markets created problems: in some respects they were not efficient, they suffered from cycles, generated inequality, and exposed people to various risks. The role of governments was to remedy these imperfections: maintain full employment, promote investment, provide public goods, equalize opportunities, and assure welfare. Specific policies, at times based on innovative, systematic blueprints, varied from country to country, but the combination of private ownership, markets, and corrective interventionism by the state was accepted by almost everyone, not just social democrats.

The result was a spectacular success. Economies grew; social expenditures grew even faster. For the first time in history, there were countries where almost everyone enjoyed basic security. Problems had remedies.

Were social democrats better at coping with problems? Since the literature on this topic is complex and immense, all I can do is to declare 
that I believe they were. At least, if in 1973 I were to decide, not knowing anything about her future life chances, whether my daughter should be a Swede or an American, I would have chosen social democracy (Lee and Przeworski, 1995). But there were always new problems. Some persisted from the past; some emerged anew. As one compares the problems enumerated by Jaures in 1902 with those mentioned in an exchange of letters among Brandt, Kreisky, and Palme (1976), the list does not get any shorter, in spite of all the remedies.

\section{Resignation?}

The stagflation crisis of the later 1970s, deepened by the surge of interest rates in 1982, undermined the 'Keynesian welfare state'. ${ }^{9}$ Forging farther in the same direction - 'fine tuning' - turned out to be a failure not only economically but also electorally. Social democrats discovered that the constraints their economies faced, internal and external, were much more biting than they had believed. And under these constraints, they could no longer strive for all their objectives. Something had to give.

The imagination of the 'new social democrats' is replete with dilemmas. Giddens, who thinks that the 'Political debate is dominated by worries about declining moral standards, growing divisions between rich and poor, the stresses of the welfare state' (1998, p. 2), finds five of them. But even more serious analyses everywhere find 'dilemmas' or at least 'trade-offs'. Iversen (this volume, p. 275) describes the current 'trilemma' facing Scandinavian - the most successful-social democracy as 'whether it wants to deepen class divisions by accepting greater inequalities, or whether it wants to create a marginalized group of people, excluded from full participation in the economy'. To appear responsible, governments must have the courage to admit that there are trade-offs. And if governments face trade-offs, they cannot promise 'everything'. There are problems that have no remedies.

Faced with the persistence of many old problems and with the emergence of new ones, some, although by no means all, social democrats draw limits to actions of the state. The state faces constraints of a macroeconomic nature: fiscal irresponsibility leads to disasters in

${ }^{9}$ I have been urged by several readers to explain why this policy regime failed. I do not know: there are just too many plausible explanations. They come in three categories: (i) the 'Keynesian welfare state' was in various ways a victim of its own success, (ii) social democratic economic regulation could not resist exogenous shocks, and (iii) bad luck. 
the newly global economy. The state must keep reassuring nimblefooted investors. In the words of Felipe Gonzàlez, 'Capital markets charge themselves with reminding that they do not trust an economic policy that does not watch inflation or deficit' (El Pais, Madrid, 9 June 1999, p. 15). And since investment responds not only to balances but also to tax rates, the constraint bites on the revenue side. The only way to satisfy it is, thus, to keep a tight control on expenditures.

This economic analysis is accompanied by a new moral tone. The state cannot be responsible for everything; individuals must bear the responsibility for their fate. 'A prime motto for the new politics,' Giddens (1998, p. 65) suggests, is 'no rights without responsibilities.' The state cannot be responsible for everyone. It can and should help those who are unlucky, but only if they are willing to help themselves. The unemployed must actively look for work; to assure them of income would induce them to be lazy, which is a 'moral hazard', a gametheoretic term transformed into a Protestant sin.

Not only does the state encounter limits to what it can do, often it does damage. Thus Giddens (1998, p. 112) cites Ronald Reagan: 'we have let government take away those things that were once ours to do voluntarily. ${ }^{10}$ Public enterprises must be sold because they are less efficient; public expenditures should be curtailed; control of monetary policy should be placed in the hands of independent central banks to assure credibility - the reader knows the rest, so I stop.

The neo-liberal policy regime at the same time favours globalization and resists its effects. Free trade, free movement of capital, free flow of ideas are the banners of neo-liberals. But while Paul Samuelson had many years ago the courage to tell US automobile executives that 'God may not have willed that automobiles be produced only in Detroit' (I cite from memory), each government resolutely defends its country from the inflow of cheap foreign products and other unwelcome consequences of globalization. Indeed, a few years ago the loss poor countries suffered from protectionism by the OECD area was exactly equal to the total flow of foreign assistance. The slogan seems to be 'Internationalism for exports; the nation for imports.' The new social democrats do not differ. After all,

Nations are ethical communities, where those involved owe special obligations to other members not always owed to others on the outside. Nations provide a focus of self-determination: the nation should develop state struc-

10 There are many aspects of Giddens's book I do not understand, but foremost among them is the subtitle: 'The Renewal of Social Democracy'. What is it that is being renewed by seeking inspiration in Thatcher and Reagan? 
tures that allow citizens to decide for themselves matters of general importance. (Giddens 1998, p. 131)

While the degree to which neo-liberal ideas permeated different social democratic parties is not the same-to cite just one example, French socialists are successfully pursuing a rather orthodox programme of job creation-policy convergence is again apparent. The dominant policy regime of our times is the neo-liberal one and, while the neo-liberal ideas softened as a result of some evident fracas, social democrats, in government and in opposition, are abandoning even some of the remedial policies.

\section{Analysis}

Obviously, if judged by its initial goals, social democracy has been a dismal failure. But, as nostalgic as one may be about the ideals of one's youth, it makes no sense to evaluate a movement by goals it had one hundred years ago. Since I do not want to repeat what has long been in print $(1985,1991)$, let me just summarize my conclusions.

(i) Participation in electoral politics was inevitable for any movement that sought a mass following. The only alternative was a revolution by a minority, which had to be and was extremely violent.

(ii) Once socialists accepted the democratic constraint, the policies they could implement depended on the support they could gain within the democratic institutions. ${ }^{11}$ Since, contrary to the optimistic extrapolations, workers never became the overwhelming majority of any electorate, social democrats could not implement their original programme of massive nationalization.

The perennial question is which strategy is superior: the 'reformist' strategy of advancing at each time only as far as the electorate permits, or a 'radical' strategy of demanding the impossible (and facing defeat) so as to educate the electorate, waiting until the electorate is ready to support the maximal programme, and then implementing everything in one sweep? This, I believe, had been the alternative of social democrats all along. They have opted for the former strategy and, most likely, they were right: no single mass movement in history survived unless it availed itself of the opportunity to improve the immediate conditions of its followers. But questions entailing counterfactuals always leave a residuum of doubt.

11 In Norway in 1928, the Labour government tried to nationalize as a minority. It lasted 3 days. 
(iii) The decision to abandon public ownership of the means of production was perhaps not inevitable but it was wise. The model of a state-owned and command-operated economy did not have political support in Western Europe and, in the light of the recent theory of 'information economics', would have been an economic disaster. Whatever social ills markets may generate, their informational role is crucial in any complex economy (even if it perhaps was not in the Soviet Union in 1928, where planning in physical terms could go a long way). But while allocating most goods by markets was the correct decision, this does not mean that the only choice was the investor-owned economy. Other alternatives were employee ownership, citizen ownership, or various mixtures of the three (three admitting some state-owned firms). Each of these alternatives faces problems: (i) an economy with employee-owned firms may not function differently from one with investor-owned firms and may, in fact, generate less employment; (ii) an economy with citizen-owned firms would generate a better income distribution and perhaps fewer public bads (diffused ownership would mean that the owners would internalize more externalities) but would face problems of monitoring. But these ideas are not quite dead: see Stiglitz's (1999b) recent rediscovery of 'stakeholder privatization'.

But the problem social democrats faced when they gave up Marxism was more profound: would they be able to replace it with a new project of a future society, an alternative vision of socialist transformation? The stake was this. Social democrats could, and did, declare commitment to full employment, equality, and justice. But to use employment, equality, or justice as criteria is not the same as to strive for an equal or a just society. Used as criteria, these values serve to identify the current problems, to choose current policies, and to evaluate their outcomes. To see them as goals, would be to conjure up a vision of society that would not generate unemployment, inequality, or injustice, to identify the mechanisms that generate these ills, and go on to transform them. Without a new project, only remedies would be left.

Let me provide just one illustration. It appears that Western European countries redistribute every year a fair amount of income while the market-generated distribution of income changes little over time within particular countries. If redistributing incomes is costly, this pattern cannot be efficient. Increasing the productive capacity of the poor - $a$ 'transformative redistribution' - would both accelerate growth and equalize incomes. ${ }^{12}$

Social democracy always stood for extending democracy from the political to the social realm. But while democracy in the political realm

${ }^{12}$ For the full argument and evidence, see Przeworski and Gandhi (1999). 
was an autonomous value for social democrats, it was only the first step. Equality of earned incomes or of life chances - distinctions came laterwas a defining feature of a socialist society. Public ownership of the means of production was the instrument to achieve equality in the Marxist vision of the future and, when nationalization turned out to be a bad idea, something would have to replace it. But what?

The repertory of socialist transformations was not empty: 'abolishing inheritance', 'social ownership' (wage-earners fund), 'freedom from toil' (reduction of labour time), 'citizen's wage' (universal minimal income) were still among the instruments. Yet, except for Sweden and, during a brief period, for France, where socialists arrived from the political wilderness promising to 'change life', the spirit of the time was well summarized by Konrad Adenauer's dictum, 'keinen experimenten', no experiments. None of these ideas was embraced by the socialist parties and, perhaps more importantly, none caught the imagination of the electorates. Even in Sweden, where the wage-earner fund was backed by powerful unions, it did not win the support of voters. The French virage of 1983 demoralized even the more timid attempts. Hence, while transformative ideas linger within the walls of the academia, the fear that voters would see them as utopian preoccupies social democratic parties.

\section{Stability and Change of Policy Regimes}

With this historical background, we can pose more analytically questions concerning the dynamics of policy regimes. Specifically, we need to identify these regimes and analyse the mechanisms through which they persist and change.

\section{(a) Policy Regimes}

Policy regimes are situations in which major parties, regardless of their partisan stripes, propose and implement similar policies. If voters learn from experience, then, after a few periods in which they observe the outcomes of a particular policy, they develop clear views about it. If they think that this policy is better than other alternatives they experienced, they vote for it. In turn, political parties, even if they have policy preferences, seeking to be elected, converge to the almost certain position of the median voter. (On voting models, see Roemer, forthcoming.) Hence, a policy regime is sustained.

For reference, I first summarize the historical description of policy regimes. 
(i) Until 1914, that is, before socialists ever held office, their programme was defined by the goal of establishing socialism, even if several parties were not adverse to realizing some immediate goals while they could. Since, except for Alexandre Millerand, who was expelled from the SFIO anyway, socialists never held office, it makes little sense to speak of differences between them and the bourgeois governments, and thus of 'policy regimes'. Note, however, that the danger that socialists would become like all other parties if they played the electoral game was the main argument of the opponents of participation, from the anarchists to Rosa Luxemburg. Roberto Michels saw it as inevitable.

(ii) When socialists held office as minority governments or members of multi-party coalitions during the inter-war period, they followed the economic orthodoxy of the time, with some distributional bias towards their constituency. They adhered to the goal of socialism and, hence, could claim that they led societies to a different future, but their policies while in office were not much different from those of their opponents. Until today, analyses of the MacDonald government as well as of the Front Populaire blame them for not breaking with the standard economic wisdom.

(iii) With the rise of Keynesianism (if that is what it was), social democrats found that they no longer needed to nationalize everything and, more influentially, that they could control the capitalist economy and remedy the social ills generated by markets. This policy was highly successful and was embraced, albeit with varying degrees, by other parties. The complaint that parties make no difference was widespread and passionate in the 1960s and 1970s: 'The working class is lost in administering its imaginary bastions. Comrades disguised as notables occupy themselves with municipal garbage dumps and school cafeterias. Or are these notables disguised as comrades? I no longer know' (Konopnicki, 1979, p. 53).

(iv) With the advent of neo-liberalism, social democrats found themselves on the defensive. Their reactions vary from accepting the fiscal constraints while continuing to pursue remedial social policies, to a wholehearted embrace of neo-liberal prescriptions. In any case, policy regimes are converging again, this time to the right. And, again, the perception that choices facing 
all governments are narrowly circumscribed and that all have to follow similar policies is widespread. And so are the voices that say that globalization deprives national constituencies of the capacity to make any meaningful political choices.

These successive policy regimes differed principally in three dimensions: forms of ownership, instruments for coping with unemployment, and international economic arrangements.

While until 1930s social democrats advocated nationalizing the means of production, they were not able to implement this programme while in office. And since the idea was anathema to bourgeois parties, no nationalizations took place (except for creation of municipal companies). Between 1936 and 1984, several banks and industries were nationalized in a number of countries, by social democrats as well as by bourgeois governments. But nationalizations were more a matter of historical accident than of partisan preferences. In fact, Sweden had the lowest share of state enterprises among the industrialized countries, while in Austria and Italy the large public sector was a post-Fascist legacy. Still the idea of selling public assets - 'privatization' (I put the word in quotation marks because it is a neologism) - was inconceivable. Standard national accounts did not even include changes of the value of publicly held assets: they had no market value, as no one could think of selling them. Nevertheless, since 1982 privatizations occurred almost anywhere governments had something to sell. In turn, no nationalizations took place, except for states assuming bad debts of private banks.

The second dimension concerns employment and unemployment. Until the 1930s again, the cyclical movements of economies were seen as obeying natural laws. Governments could protect incomes, but could not counteract the cycles. Swedish social democrats lost office twice in the 1920s over the issue of unemployment compensation but the only policy difference between the left and the right was whether or not to compensate the unemployed. At least since the Second World War, governments of all partisan stripes have become committed to the goal of 'full employment': with great fanfare, the OECD unveiled a new blueprint for full employment every 5 years. These blueprints evolved, but the essential instruments were Keynesian: inflating the economy in the face of high unemployment, with public works as the most effective tool. This policy was almost universally abandoned ${ }^{13}$, on the grounds

13 Except for the United States during the Reagan era, where it was an unintended consequence of divided government. 
that demand stimulation increases inflation without having an effect on employment.

The third dimension along which policy regimes experienced profound changes was trade and exchange-rate arrangements. This is, however, a more complex story, and I will not delve into it.

In turn, differences with regard to welfare policies were much less pronounced. ${ }^{14}$ The social protection net was built gradually and through varied paths: social christians were as dedicated to protecting material welfare as social democrats, while some bourgeois governments of other inspirations built it in order to thwart a revolutionary threat. And it has not been dismantled. Even Margaret Thatcher did not succeed.

\section{(b) Policy Innovations}

The major policy innovation of social democrats was the very idea that capitalist economies can be regulated and the effects of markets can be corrected: what is referred to these days as 'the Keynesian welfare state'. In turn, the major innovation of neo-liberals was the claim that well-designed market institutions spontaneously maximize the welfare of society, with only a minimal policy intervention.

Each of these innovations was rationalized by a theoretical blueprint. From Karl Kautsky's The Class Struggle, through the last chapter of Keynes's General Theory, Friedmans' Free to Choose, to the 'Washington Consensus' (Williamson, 1990), each policy regime found a theoretical articulation founded in contemporary economic theories. Even if some ideas were formulated only after the policies they justified were already being implemented, they had an autonomous effect on routinizing the particular policy regimes by persuading the élites, and even the masses, that these policies are based on reason. I remember that in the late 1980s everyone in the United States believed that 'deficits cause inflation' and, even if no one I ever asked, from my father-in-law to taxi drivers, could spell out the causal chain, they all accepted the authority of the economic theory.

But even if new ideas are available, to explain the changes of policy regimes is difficult. Policy innovations can occur in two ways: either some party wins an election offering the old policy and then surprises voters by switching to a new one, or a party campaigns and wins an election proposing a new policy and implements it once in office. Stokes (1999) studied the recent cases in which parties campaigned on traditional platforms and, once elected, switched to neo-liberal policies. I

${ }_{14}$ Perhaps again with the exception of the United States, which is sui generis, as it never had a major social democratic party. 
will concentrate on the second path. The question, then, is whether and, if ever, under which conditions, would a party offer a new policy, be elected, and implement it with success.

The conclusions of my reasoning (spelled out in Przeworski, 1999), are the following. (i) There are circumstances under which a party would propose a new policy, be elected, and implement it successfully. (ii) This will occur if a combination of particular conditions occurs, specifically, (a) the party is convinced that the new policy is better than the old one, $(b)$ voters think the old policy is not very good, $(c)$ voters believe that the party cares about their welfare rather than about pursuing the new policy for its own sake, and $(d)$ the new policy does not run into bad luck when it is being implemented.

The intuition behind this reasoning is the following. When voters do not know what to think about the new policy, they take a party's proposal to do something new as a signal that this party knows something they (and the other party) do not know, as long as they think that the party which offers the new policy is responsible and they see status quo as not good. Unless the innovating party is unlucky, voters will vote for this policy again. And note that, if the innovating party had in the past followed or proposed the same policy as the other party, voters will tend to think that it is responsible and that it deviates from the old policy because it does believe that the new policy is better.

I think that these conclusions are consistent with the historical experience. To give just a few examples, the Swedish SAP campaigned in the election of 1932 with a programme that was new, even if it realized how new it was only after its initial success, so that the party heralded its policy as revolutionary only in 1936. It was elected in 1932 in the midst of an economic crisis (and a political scandal), so that voters thought the old policy was bad. The SAP was lucky, because demand for Swedish exports was fed by the German rearmament. The elections of Margaret Thatcher and Ronald Reagan also fit this pattern (even if the policy shift in the United States was marked as of 1978, in the middle of Jimmy Carter's term). They both believed that neo-liberal policies are better and advocated them in elections, while voters were experiencing a double-digit inflation with no growth. ${ }^{15}$ Moreover, Reagan had the good luck of having a Congress that kept the spending up, while Thatcher gained popularity because of the Malvinas-Falklands war.

More generally, policy regimes changed amidst economic crises, when voters thought that old policies did not work well. The parties that proposed and implemented policy innovations believed that new

${ }^{15}$ Moreover, as Kalyvas (1994) argues, British public opinion turned against nationalizations because the Labour government ran into the oil crisis. 
policies would be better and their beliefs were founded in ideas of economists. Good luck helped in persuading voters that the new policies were effective.

\section{Social Democratic Perspectives}

Is a social-democratic-led policy innovation possible today, or is it inevitable that social democrats become 'social liberals' for the foreseeable future? My views are the following. (i) There is an ample room for a policy innovation because the constraints which paralyse social democrats are not as tight as they tend to believe. (ii) Voters' initial enchantment with neo-liberalism is waning in the face of persistently high unemployment in some countries and growing wage disparities in other countries. (iii) Proposing a new policy is a risky bet, since its success depends to some extent on luck. I concentrate on the first point, concerning the purported dilemmas.

The first belief which motivates the current neo-liberal policy regime is that the state is 'too big'. This belief has two versions: the first is a theoretical claim that a big state is bad for economic efficiency, the second is an empirical claim that a big state scares investors. Much of the former is just an ideological fantasy, even if at times mathematically adorned. My favourite is an article which begins by assuming that state expenditures do not enter as inputs into production or as sources of utility for households and then concludes that taxes are bad for growth (Rebelo, 1991). The state can be too big: this much no one will question. But this does not imply that everywhere it is. The following conclusions, I believe, are consistent with the current state of economic theory. (i) There are equilibria in which there is unemployment either because of insufficient supply or insufficient demand. (ii) There are situations in which state subsidies to investment foster growth. (iii) Private insurance markets are never efficient in the presence of differentiated risks: universal compulsory insurance schemes, in which low-risk categories subsidize high-risk categories, dominate markets by efficiency criteria even in the presence of moral hazard.

Hence, (i) demand should be sometimes restricted and sometimes expanded, (ii) some productive role for the state is optimal for growth, ${ }^{16}$ and (iii) some compulsory universal insurance schemes are optimal for

${ }^{16}$ Barro's (1990) estimate of the optimal size of public productive expenditures is surprisingly high, about 25 per cent of GDP; Cheibub and Przeworski (1997) discovered that the state is too small in most countries by the criterion of equalizing marginal products of the public and the private sector. 
current welfare. Since in all the three aspects the optimal solution is an internal one, the state may be too big or too small under the particular conditions. But a blanket programme of reducing the state is just rightwing dogmatism.

The empirical claim that a big state scares the investors is more complicated. In a closed economy, taxes on income are supposed to reduce investment. Almost all economists believe this much, even if Stiglitz (1999b) argued recently that current taxes may forecast lower future interest rates and may in fact stimulate investment. Statistically, the hypothesis that taxes reduce investment almost never fares well, but this may be a matter of data and specification. In any case, closed economies are history: we live in the era of globalization.

Like El Niño, 'globalization' is a God-given gift for all governments. It is a cause that is external, omnipresent, and inexorable. Whatever successes governments achieve, these can be attributed to their wise actions. Whatever failures there are, can be explained residually. There seems to be no politician who does not proclaim that globalization narrowly circumscribes their margin of manoeuvre. Since the entire problematic is a conceptual muddle and serious research is still scarce, summarizing the current state of knowledge is risky. Nevertheless, I think that these are the best beliefs one can hold at the present. (i) Most of the effects attributed to globalization are due to something else, many to technological changes (Glyn, 1998b). ${ }^{17}$ (ii) The margin of manoeuvre may be very narrow with regard to some policies but broad with regard to other policies. Specifically, in the light of Mosley (1999), it appears that investors buying government obligations pay close attention to the inflation rate and the current account, but not to other indicators, perhaps surprisingly including the deficit and the tax rates, as well as allocations of expenditure. In turn, direct investment seems insensitive to policies in general. The effect of economic 'fundamentals' on capital flows is hard to determine. (i) Governments were always constrained by the reactions to their policies of private investors; most investment is domestically financed anyway, and globalization has at most an incremental effect. (ii) Reactions to external shocks are not uniquely determined by the nature of these shocks. Even if most governments treat it as inevitable, to cite Stiglitz (1999a) again, it is far from apparent that raising domestic interest rates is the best response

17 For example, everyone in the less developed countries seems to believe that they are losing jobs owing to the inflow of cheap exports from the technologically advanced economies, while everyone in the developed countries seems to think that they are losing jobs because of the inflow of cheap exports from the low-wage countries. Obviously, without a general technological change, something here does not add up. 
to speculative flows against a currency. Effects of external shocks are mediated by the domestic political and economic institutions (Boix, 1999). (iii) Capital flows are subject to multiple ('sunspot') equilibria and the question whether they are driven by economic fundamentals seems wide open. Note that I am not arguing that the volatility of capital flows is costless, nor that open trade has no effect on income distribution, but only that we just simply do not know as of today how 'globalization' works. At the moment it appears to be mostly a smoke screen.

Some constraints, however, are domestic. Two concern the welfare state. The first is that, as it developed in the OECD countries, the welfare state was based on the assumption of a particular demographic and household structure. As this structure changed - and it changed drastically - the current welfare policies are simply poorly designed for the contemporary advanced societies (Esping-Andersen, 1999). Moreover, faced with the combined effect of demographic change and a rise of unemployment, the welfare state suffers from an acute fiscal strain. The second constraint is political. People were willing to support universal compulsory insurance schemes when many of them faced the same risks. As these risks have become differentiated, they are more inclined to opt out for private insurance schemes.

Finally, to implement their programmes, parties must win elections. Hence, they must anticipate who would support their programmes. Class analysis in the Marxist sense-class defined in relation to the ownership of the means of production - illuminates little about contemporary societies. Appeals to 'the exploited' would be anachronistic: a central problem of contemporary societies is that there are millions of people who dream about being exploited. One can obviously think of class in different terms. But while class analysis may elucidate the patterns of voting-income, education, and occupation are still good predictors of partisan orientations - it is irrelevant for understanding who wins elections. The power of class is inframarginal, while political competition takes place at the margin. In most countries, the difference between the electoral support for social democratic and the largest bourgeois parties (or between left and right coalitions) remains very small. Hence, small vote changes at the margin, amplified by disproportionalities of electoral systems, shift partisan control. And this implies that, to the extent to which they can be identified, parties must compete for the same voters.

This much about constraints. I am far from certain that they are exactly what I described them to be: particularly with regard to globalization, it is hard to tell. But many of the 'dilemmas' appear to be just excuses: the famous 'big trade-off' between efficiency and equality is not a trade-off at all if the poor cannot educate their talented off- 
springs (or, in general, if they are credit-constrained) ${ }^{18}$ Iversen's 'trilemma' would vanish if the supply of skills would catch-up with demand for them; Gonzàlez's fiscal constraint can be relieved by administrative reforms that would reduce the cost of delivering social services (Bresser Pereira, 1998); of Giddens's five 'dilemmas' none is that in a logical sense of this term.

The choice facing social democrats is thus which strategy to pursue. One strategy is to accept the diagnosis of the problems and of the constraints by their opponents and to claim that social democrats have better solutions. The problems identified by Thatcher or Reagan are real, but their solutions are wanting, while the old left clings to an outmoded view of the world. Hence, we are the new social democrats: not responsible for the past, better prepared for the new world than the neo-liberals. This is basically a strategy that takes voters' beliefs as they are and accommodates to these beliefs, while staking the political claim at higher competence, honesty, compassion, or whatever the case may be. The alternative strategy is to tell the voters that they are wrong, that they have been misled by neo-liberals, that the problems and the constraints are not what voters believe, and that different policies are possible and will be successful.

The second strategy is obviously much more risky. If social democrats place themselves close to neo-liberal policies, they have a good chance that any minor accident may generate their electoral victory. If once in office they pursue the neo-liberal policies with moderate success, voters will be unable to update their beliefs and will keep voting for them until some new accident occurs. But if social democrats try to persuade voters educated by neo-liberals that they are mistaken, there is going to be a large policy distance between parties. If they are in opposition, social democrats may keep losing; if they are in government and pursue currently unpopular policies, they may be defeated unless they do particularly well. In the past, there were periods when social democrats took the risk and were lucky: Sweden in 1932 is the prime example, but so was Bruno Kreisky's expansionist response to the recession of 1975 (Guger, in this volume) and, if perhaps more timidly, Lionel Jospin's government's current job-creation policy. But many times such policies failed, whether under François Mitterrand in France, who had the bad luck that the world economy did not pick up in time (Lordon, in this volume) or under PASOK in Greece before 1985 (Tsakolotos, in this volume).

${ }_{18}$ See the already vast literature that shows that income inequality is bad for economic growth. 
The success of the latter strategy requires innovative ideas, the courage of conviction, and luck. Such combinations have been historically rare, which is why policy regimes last for decades and change infrequently. All I can say is that if this reasoning is correct, then the quality of ideas, and the courage to pursue them, matter.

\section{Conclusions}

Whether or not social democratic and bourgeois governments pursue similar policies is not what matters. If some policies are better than others, if different parties share the understanding of the constraints, and if voters learn from experience, then most of the time parties of different stripes will follow similar policies. Even if parties have different ideal points in the space of outcomes, they will have proximate ideal points in the space of policies if their politicians believe that they face trade-offs between objectives. Policies diverge when there are leaders who find ways of overcoming real trade-offs or who free their imagination from illusory ones. They converge as the experience with new policies accumulates. What does matter is which policy regime dominates everyone's thinking: who leads and who follows.

If this analysis is correct, then the periodic disenchantment with democracy - the widespread perception that elections make no difference - is both justified and misplaced. It is justified because most of the time, no one, whether voter or politician, knows anything better to do. But there are moments when the future is in voters' hands. Whenever a party does propose to do new things, the voters' decision is crucial. Democracy, it seems, works in spurts.

Let me end with a qualification. The focus of my analysis was economic policy. But I think that there has been a persistent difference between social democracy and the right, namely that the right has been traditionally authoritarian, indeed, more statist than social democrats in the political realm. Even today, for all the talk about reducing the state, the main social policy of neo-liberals in the United States is to build more prisons. Hence, I see the language of 'new social democrats'-decline of moral values, strengthening the family, crime-as new indeed. And as ominous. 